\title{
Sugar and Alcohol Based Onion Extracts as Growth Supplements of Broilers
}

\author{
Webel Glenn C. Dublado, Nelfa C. Gil, Redney M. Solomon \\ Southern Leyte State University, Sogod, Philippines \\ Email: wgcdublado@yahoo.com
}

How to cite this paper: Dublado, W.G.C., Gil, N.C. and Solomon, R.M. (2016) Sugar and Alcohol Based Onion Extracts as Growth Supplements of Broilers. Open Access Library Journal, 3: e3017.

http://dx.doi.org/10.4236/oalib.1103017

Received: August 31, 2016

Accepted: September 24, 2016

Published: September 27, 2016

Copyright $\odot 2016$ by authors and Open Access Library Inc.

This work is licensed under the Creative Commons Attribution International

License (CC BY 4.0).

http://creativecommons.org/licenses/by/4.0/

\begin{abstract}
The study assessed the growth performance of 75 Cobb broilers as influenced by onion extracts supplementation. The animals were divided into five treatments with three replications. Birds in Treatment 1 received antibiotic and vitamins while in succeeding Treatments onion extracts were used with $0.125 \%$ and $0.250 \%$. Alcohol and sugar extractants were used. It was found out that there was no significant difference between birds that received antibiotic and vitamins and broilers supplemented with onion extracts to the growth of broilers. Further, birds that received the sugar based onion extracts has better gross margin as compared to other treatments.
\end{abstract}

\section{Subject Areas \\ Agricultural Science}

Keywords

Onion Based Concoctions, Broilers

\section{Introduction}

Herbs are small plants that are leafy, lack woody stems and most of the time aromatic. They are popular as flavorings of food especially in cuisines. In olden times, herbs are known to have medicinal properties and are used as local folk remedies for various ailments. The spices garlic and onions have been known to have beneficial properties [1]. Both spices belonged to same Genus in its taxonomy where onion is Allium cepa and garlic is Allium sativum. Onions, however are cheaper compared to garlic and often in excess supply in the market and spoil most often. Thus the excess onions can be used as supplement to animals. Onion plant is a herbal spice of culinary importance. It thrives well in mild climates with warm and dry conditions [2].

The research was about the comparative effects of alcohol and sugar based extracts as 
a supplement on the growth performance of broilers. The juice of the onion bulb was using alcohol from beer, gin and sugar. The extracts were made a supplement to broilers via drinking water.

Hossain [3], evaluated eleven herbs and spices as alternatives to antibiotic supplementation to broilers. Their findings revealed 1\% black cumin, $1 \%$ cinnamon and $1 \%$ chili powder can be used as a substitute of antibiotics in the diet of broilers. Onion was used as supplement in drinking water of broilers in the works of Dublado [4]. It extracted the onion juice in a fermented form and found that birds which consumed the extracts had comparable performance to birds that consumed antibiotic and vitamin supplements. Kim [5], extracted herbal juices using wine alcohol and referred to them as oriental herbal juices. The extracts can be used in poultry and livestock as supplement given at $0.1 \%$ dilution rate for three times a week.

Previous studies [5] [6] used different herbs and spices as supplements for broilers. This study attempted to compare the extracts of one herb which is onion using alcohol from common alcoholic drinks and sugar. The plant was used since it's a common condiment that can be of excess supply in the market and can be easily integrated into a farming system.

\section{Methodology}

The research used 75 heads of Cobb broilers equally divided into five treatments with three replications each. Each replicate had five samples and used the complete random design. The preparation of the alcohol-based extracts was patterned from the methods of Kim [5]. This was a modification of the methods for oriental herbal nutrient preparation. One kilogram of onion bulbs were chopped and placed in a pail. One bottle of beer $(325 \mathrm{ml})$ was added and the mixture was set aside for 12 hours. After the initial process, two bottles of gin $(650 \mathrm{ml})$ were added to the mixture, and it was stored in a cool place at $29^{\circ} \mathrm{C}$ for seven days for fermentation. The preparation of the sugar based onion extract was outlined from the works of Miller [6]. A ratio of $0.5 \mathrm{~kg}$ sugar to $1 \mathrm{ki}$ logram of onion bulbs was the base of the extract. The onions were cut into small pieces first utilizing a knife; were minced and placed in a pail. Then the materials were mixed with brown sugar stored in a cool place. The concoctions were harvested on the $7^{\text {th }}$ day of fermentation. The extracts were collected by decantation, and remaining mixture was hand squeezed for the removal of the juices. The collected material was stored in a PET bottle and was placed in a cool place.

The broilers were brooded in a collective pen per treatment and when it reached 14 days old were sorted for replication. Treatment one was the control group with antibiotic (Ciprofloxacin with Tylosin tartrate, Chlortetracycline, Cotrimazine), and vitamin supplement (Multivitamins with Electrolytes WSP). The birds in this treatment received 1 teaspoon per gallon antibiotic and vitamin preparation. In treatment two, the animals received $0.125 \%$ ( $1 \mathrm{tsp} / \mathrm{gal}$ ) of sugar based onion extracts (SBOE) and in Treatment 3 it received $0.250 \%$ ( $2 \mathrm{tsp} / \mathrm{gal}$ ). In treatment four, the animals received $0.125 \%$ alcohol-based onion extracts (ABOE) while in the fifth treatment; it received 
$0.250 \%$ of the ABOE. The supplements were given by way of drinking water at a frequency of 3 times a week for 6 hours. The dosage of the antibiotic and vitamin supplementation was based from its manufacturers' literatures [7] [8].

The birds were harvested on the $35^{\text {th }}$ day. Feed was given ad libitum with at least 15 to 20 minutes interval. Commercial medium to high density-feeds were used. All the supplements were given via drinking water. The antibiotic and vitamin preparations were given for three days, six hours per day for three times a week.

The quantity of feed as well water given to the flock was noted daily, and the average weight was taken in a weekly basis. The production parameters of feeds conversion ratio (FCR), average live weight, (ALW) livability, and age were observed. The production efficiency factor was computed. The PEF was the measurement used to gauge the productivity of the animals. The values were computed as the products of the ALW and Livability divided by the products of FCR and Age. The quotient was multiplied by a factor of 100 [9], FCR is computed as quotient of total feeds consumed by the animals and its total live weight. The FCRs as well as the PEFs of the treatments were compared and tested for ANOVA. Values with a significant difference were compared using LSD test. The cost to produce in a per kilogram basis and the gross margin were also computed.

\section{Results and Discussion}

A direct indicator of performance is the growth of broilers as manifested by its increase in average live weight (ALW). It is pointed out in Table 1 that the birds in the Treatment 2 had the heaviest ALW compared to the rest of the treatments. Numerical values of ALWs however, did not show any significant difference $(\mathrm{p}=0.734)$. This means that the weights of birds were comparable to each treatment.

The effects of onion based concoctions the growth of broilers can be compared to the effects of antibiotic and vitamin supplementation. This is attributed to the presence of its antioxidant properties. These active ingredients like the flavonoids have anti-oxidant properties [10]. It theoretically boosts the broilers immune system protecting the animals from diseases. Further, it directs most nutrients to growth instead of spending it for repair of damage tissues [11].

The health status of the animals can be observed by the high harvest recovery or livability. In Table 2 , Treatment 5 had the lowest harvest recovery among treatments. The mortality however was caused by heatstroke and not of infectious etiology.

Table 1. Average live weight of broilers in Kilograms.

\begin{tabular}{cccc}
\hline Treatment & Mean & Std. Deviation & Std. Error \\
\hline 1.00 & 1.64 & 0.15 & 0.04 \\
2.00 & 1.68 & 0.12 & 0.03 \\
3.00 & 1.67 & 0.19 & 0.03 \\
4.00 & 1.62 & 0.20 & 0.05 \\
5.00 & 1.58 & 0.45 & 0.12 \\
\hline
\end{tabular}


Table 2. Livability of broilers during harvest.

\begin{tabular}{cccc}
\hline Treatment & Quantity Placed & Quantity Harvested & Livability \% \\
\hline 1 & 15 & 15 & 100.00 \\
2 & 15 & 15 & 100.00 \\
3 & 15 & 15 & 100.00 \\
4 & 15 & 15 & 100.00 \\
5 & 15 & 14 & 93.33 \\
\hline
\end{tabular}

Table 3. Feeds conversion ratio of the broilers.

\begin{tabular}{cccc}
\hline Treatment & Mean & Std. Deviation & Std. Error \\
\hline 1.00 & $1.85_{\mathrm{a}}$ & 0.19 & 0.05 \\
2.00 & $1.79_{\mathrm{a}}$ & 0.14 & 0.03 \\
3.00 & $1.91_{\mathrm{ab}}$ & 0.16 & 0.04 \\
4.00 & $2.02_{\mathrm{b}}$ & 0.26 & 0.07 \\
5.00 & $2.00_{\mathrm{b}}$ & 0.36 & 0.09 \\
\hline
\end{tabular}

Another parameter that measures the conversion of the broilers' taken feeds into the weight is the feeds conversion ratio (FCR). In this measurement, the lower the numeric value the better the interpretation. ANOVA computations indicate that the birds have a significant difference in their FCRs $(\mathrm{p}=0.040)$. LSD test revealed that broilers in Treatments 4 and 5 had lowest FCRs. Subscript in the subscript denotes statistical significance between treatments. Treatments 1 and 2 had the best FCR while treatment 3 had a moderate FCR value among treatments.

Broilers in Treatments 1 to 3 need about 1.85 to $1.91 \mathrm{~kg}$ of feeds to change it into $1 \mathrm{~kg}$ of the broilers' weight. The birds in Treatment 4 and 5 need about $2 \mathrm{~kg}$ of feeds to change it into $1 \mathrm{~kg}$ of its weight. The conversion of feeds into the animal's weight depends upon the health conditions of the animal. A broiler that has no disease can efficiently transform the consumed feeds into its weight successfully than the animal that has a health problem. In Table 3, the birds that received the ABOE were less efficient in converting the feeds into the broilers' weight as compared to the birds that received the antibiotic and vitamin supplement as well as SBOE. This is attributed to the diluted form of the plant concoction. The preparations of ABOE involved the mixture of alcohol which made the extracts diluted compared to the vitamin and antibiotic preparations. The allicin present in onion extract that can also act as a stimulant of digestive enzymes was not be concentrated enough to cause stimulation of enzymes.

The overall performance of the broilers is quantified by the performance efficiency factor $(\mathrm{PEF})$. The quantified performance is not statistically significant $(\mathrm{p}=0.190)$ at 0.05 level of significance. This means that the performance of birds supplemented with ABOE and SBOE were at par with the birds supplemented with antibiotics and vitamins (Table 4).

The growing performance of broilers in general is a result of many factors. One of 
Table 4. Performance efficiency factor.

\begin{tabular}{cccc}
\hline Treatment & Mean & Std. Deviation & Std. Error \\
\hline 1.00 & 257.22 & 47.63 & 12.30 \\
2.00 & 270.57 & 38.33 & 9.90 \\
3.00 & 254.81 & 40.40 & 10.43 \\
4.00 & 234.63 & 57.30 & 14.79 \\
5.00 & 238.71 & 37.38 & 9.99 \\
\hline
\end{tabular}

which is management. The presence of a proficient management system, nutrition and the absence of diseases are other considerations for a good performance. It has been pointed out that the broiler performance as quantified by the PEF of the birds that received the ABOE and SBOE is statistically the same with those birds that received the antibiotic and vitamin supplement. This just substantiated the previous findings that herbal concoctions have positive effects to the performance of broilers [12]. The performance of the broilers that received the onion extracts is attributed to the interaction of the onion's active ingredients. These ingredients like allicin serve as digestive stimulant that theoretically triggers the release enzymes for the efficient digestion and absorption of nutrients.

Cost-benefit analysis revealed that the birds which received the SBOE had a good profit margin as compared to the birds that received the ABOE. The preparation of $\mathrm{ABOE}$ is more expensive than SBOE due to the addition of wine alcohol. Further birds that had been given with $\mathrm{ABOE}$ were heavier than those with $\mathrm{SBOE}$ as supplement.

\section{Conclusion}

The supplementation of SBOE and $\mathrm{ABOE}$ has positive effects. Broilers supplemented with these extracts have performance comparable to broilers supplemented with antibiotic and vitamins. Based from the results of the study, the onion extracts using sugar as an extractant is better than the onion extracts that used alcohol.

\section{References}

[1] Bauer, J. (2015) Health Benefits of Garlic and Onion. http://www.joybauer.com/food-articles/allium-vegetables.aspx

[2] Mamaril, V.R., Sicat, S.R., Sison, E. and Buño, T. (2013) Production Guide of Onions. http://www.bpi.da.gov.ph/bpioldsite1/pdf/PRODUCTIONGUIDE-ONION.pdf

[3] Hossain, M., Howlader, J., Islam, M. and Beg, M. (2014) Evaluation of Locally Available Herbs and Spices on Physical, Biochemical and Economical Parameters on Broiler Production. International Journal of Plant, Animal and Environmental Sciences, 4, 217-323.

[4] Dublado, W.G., Dayola, Y., Albert, A. and Solomon, R. (2013) Fermented Onion (Allium cepa) Juice Supplementation to Broilers. Journal of Science Engineering and Technology, 6, 73-78.

[5] Kim, C., Chang, S., McGinn, J., Weinert, E., Miller, S., Ikeda, D. and DuPonte, M. (2014) Natural Farming: Oriental Herbal Nutrient. www.ctahr.hawaii.edu/freepubs 
[6] Miller, S.A., Ikeda, D.M., Weinert, E.W., Kim, C., McGinn, J., Cheyanne, K. and DuPonte, M. (2013) Natural Farming: Fermented Plant Juice. www.ctahr.hawaii.edu/freepubs

[7] The Filipino Vet (2013) Ciprotyl. http://www.thefilipinovet.com/profile-product-search.html\&alpha=20120445\&keyword=Q 2lwcm90eWwgV1NQ\&prodid=20120380

[8] UNAHCO (2013) Vetracin Classic. http://unahco.com/global/module.php?LM=products\&id=1190952278972U

[9] Ross Broiler Management Guide. http://en.aviagen.com/assets/Tech_Center/Ross_Broiler/Ross-Broiler-Handbook-2014i-EN.pdf

[10] Charanjit, K., Joshi, S. and Kapoor, H.C. (2009) Antioxidants in Onion (Allium cepa L.) Cultivars Grown in India. Journal of Food Biochemistry, 33, 184-200. http://onlinelibrary.wiley.com/doi/10.1111/j.1745-4514.2009.00212.x/abstract;jsessionid=8 C3F300C11CAF100E150DE434FCD60A3.f04t04?deniedAccessCustomisedMessage $=$ \&userI sAuthenticated $=$ false http://dx.doi.org/10.1111/j.1745-4514.2009.00212.x

[11] Devasagayam, T., Tilak, J., Boloor, K., Ketaki, S., Saroj, G. and Lele, R. (2004) Free Radicals and Antioxidants in Human Health: Current Status and Future Prospects. JAPI, 52, 794803.

http://www.panelamonitor.org/media/docrepo/document/files/free-radicals-and-antioxida nts-in-human-health.pdf

[12] Portugaliza, H.P. and Fernandez Jr., T.J. (2012) Growth Performance of Cobb Broilers Given Varying Concentrations of Malunggay (Moringaoleifera Lam.) Aqueous Leaf Extract. Online J. Anim. Feed Res. http://www.science-line.com/index

\section{Submit or recommend next manuscript to OALib Journal and we will provide best service for you:}

- Publication frequency: Monthly

- 9 subject areas of science, technology and medicine

- Fair and rigorous peer-review system

- Fast publication process

- Article promotion in various social networking sites (LinkedIn, Facebook, Twitter, etc.)

- Maximum dissemination of your research work

Submit Your Paper Online: Click Here to Submit

Or Contact service@oalib.com 